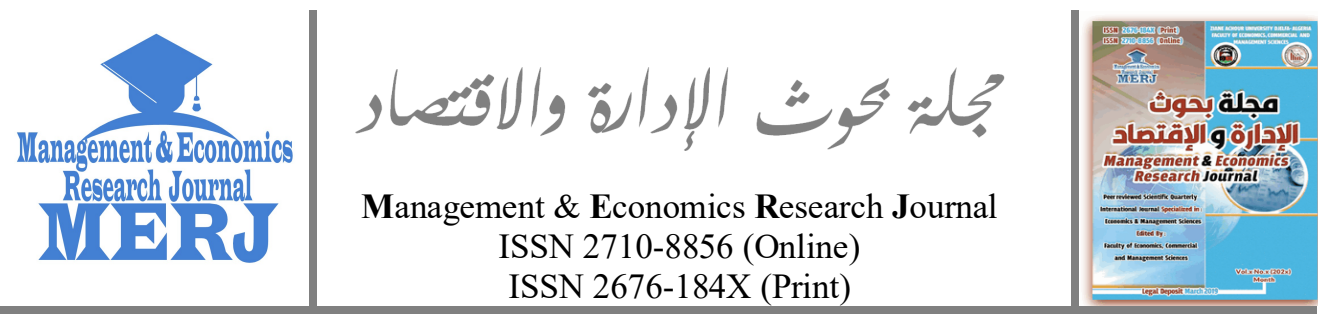

Management \& Economics Research Journal, Vol. 2 No.4 (2020), pp. 10-26

doi https://doi.org/10.48100/merj.v2i4.122

Check for updates

\title{
The Impact of Tourism Industry on Economic Growth: The Case of Algeria (Cointegration \& Causal Analysis)
}

\author{
Boumedyen Taibi ${ }^{1}$, Khadidja Lamri ${ }^{2}$ \\ ${ }^{1}$ Associate Professor, University Dr. Tahar Moulay, Saïda (Algeria) \\ $\triangle$ didenmajor@yahoo.fr \\ ${ }^{2} \mathrm{PhD}$ student, University Dr. Tahar Moulay, Saïda (Algeria) \\ $\triangle$ Lamrikhadidja2222@gmail.com
}

Received: 24-04-2020

Accepted: 15-07-2020

Published: 22-09-2020

\begin{abstract}
:
This research paper aims to analyze the relationship between tourism and economic growth in Algeria from 1995-2018. To this end, an economic model was estimated according to the econometric methodology (cointegration relationship test, vector error correction model (VECM), and the Granger causality test). The results showed that the number of tourists has a negative impact on economic growth in Algeria, which means that Algeria depends on other variables to increase economic growth, such as oil revenues.
\end{abstract}

Keywords: Causality, Cointegration, Economic Growth, Tourism, Algeria. JEL Codes: C1, O4, Z32.

\section{Introduction}

Tourism is a human activity that satisfies the person and his values, society and objectives, and the State and its budgetary ambitions. This human activity has been institutionalized over the generations since its emergence in the 19th century, passing from a shared individual need of a social class (the English aristocracy) to an aroused, oriented, cultivated, and democratized need. All of this explains the growing interest of small and large companies in the States for this significant source of income.

Tourism has become a major driver of social and economic progress

- Corresponding author: University Dr. Tahar Moulay, Saïda (Algeria).

[ $\square$ didenmajor@yahoo.fr]

Faculty of Economics, Commercial \& Management

Sciences, Ziane Achour University of Djelfa, BP

3117, Djelfa - Algeria 
through job creation and companies, infrastructure development, and earned export earnings. It is considered one of the leading service industries in the global economy as the economic flows which result from international tourism have become vital factors in economic growth and international economic relations in many countries.

Tourism is considered one of the Mediterranean countries' most important economic activities. Due to their geographic position at the heart of three continents, these countries attract more than $30 \%$ of international tourist arrivals, which generates jobs and revenues. Algeria is part of the Mediterranean basin, but it has not managed to develop the tourism sector with a very low number of foreign tourists (2657000 tourists in 2018) and to rank well compared to competing destinations like Morocco, Tunisia, Turkey, Spain, Italy...etc.

Today, governments have focused their attention on the development of the tourism sector, thanks to these economic advantages. Therefore, developing the tourism sector is a critical priority for governments, which requires medium and long-term policies and planning to achieve tourism attractiveness.

In Algeria, hydrocarbons are still the chosen sector so far, bearing in mind that the barrel of oil is somewhat volatile. Algeria must search for other sectors to rely on and search for new opportunities at the international level to diversify its sources. However, in the context of the current global economy, tourism is of particular interest.

In this sense, our main problem in this paper is:

What is the impact of tourism on economic growth in Algeria?

To answer this problem, we propose four main hypotheses for our research, which are:

- The tourism sector has a positive impact on economic growth in Algeria.

- The tourism sector has a negative impact on economic growth in Algeria.

- The NBT and REER caused the GDP.

- The NBT and REER do not cause the GDP.

\section{Review of literature $\&$ the theoretical framework}

To lay the foundations of research, we addressed through this paper the presentation of some literature review highlighting the essential results reached.

\subsection{Review of literature}

In this section, we will try to present the most important results of 
the review of literature related to tourism and economic growth.

\subsubsection{The study of (Arslanturk et al., 2011) entitled (Time-varying linkages between tourism receipts and economic growth in a small open economy):}

This study investigates the causal link between tourism receipts and GDP in Turkey for the period 1963-2006. The study uses the rolling window and time-varying coefficient estimation methods to analyze the Granger causality based on Vector Error Correction Model (VECM). The paper's findings indicate no Granger causality between the series. The findings from the time-varying coefficients model based on the state-space model and rolling window technique show that GDP has no predictive power for tourism receipts. However, tourism receipts have a positive predictive content for GDP following the early 1980s.

\subsubsection{The study of (Ekanayake \& Aubrey, 2012) entitled (Tourism development and economic growth in developing countries):}

It aims to investigate the relationships between tourism development and economic growth in developing countries using the newly developed heterogeneous panel cointegration technique. This study examines the causal relationship between tourism development and economic growth using Granger causality tests in a multivariate model and using the annual data for the 1995-2009 period. The study finds no evidence to support the tourism-led growth hypothesis. The results of the FMOLS show that, though the elasticity of tourism revenue concerning real GDP is not statistically significant for all regions, its positive sign indicates that tourism revenue positively contributes to developing countries' economic growth. The study's results suggest that governments of developing countries should focus on economic policies to promote tourism as a potential source of economic growth.

\subsubsection{The study of (Ben Zaarour \& Satour, 2017) entitled (Tourism and economic growth in Algeria):}

This study investigates the relationship between economic growth and tourism development in Algeria. This research aims to empirically test the long-term relationship between economic growth and tourism development for annual data collected between 1995 and 2014. The study uses a multivariable model that includes gross domestic product as a proxy of economic growth and a variable reflecting the tourism economy, such as the arrival of international tourists and income from expatriate spending. 
Boumedyen Taibi \&

Khadidja Lamri

The Impact of Tourism Industry on Economic Growth: the

Case of Algeria (Cointegration \& Causal Analysis)

Other relevant variables are added to estimate the econometric model.

\subsubsection{The study of (Harrats \& Ramdani, 2018) entitled (Studying the causal relationship between tourism investment and tourism growth in Algeria using Toda and Yamamoto methodology):}

This study aims to find the causal relationship between tourism investment and tourism growth in Algeria, where the Toda and Yamamoto methodology; using the methodology of Toda and Yamamoto, which is based on the Vector Autoregression (VAR) model, the study concluded that there is a one-way causality from tourism investment to domestic tourism raw production.

\subsection{The theoretical framework}

During the 20th century, tourism gradually established itself as an essential element of social and economic life, first in Europe and North America, then Asia, and later in other parts of the world. In this section, we will present general tourism information.

\subsubsection{Definition of tourism}

"Tourism is a new phenomenon that has emerged in everyday reality for less than half a century. However, it experienced such rapid expansion and generalization in society as a commonplace and a naturally constitutive element of this daily life" (Cazes, 1989, p. 07).

One of the earliest definitions of tourism was given by an Austrian economist, Hermann V, Schullard, in the year 1910, who defined it as: "the total of operators, mainly of an economic nature which directly relates to the entry, stay and movement of foreigners inside and outside a certain country, city or region" (Raj, 2002, p. 69).

For the World Tourism Organization (WTO), "tourism is a trip away from your usual place of residence for more than 24 hours but less than 04 months, for leisure purposes, a professional purpose (business tourism) or a health goal (health tourism)" (Camilleri, 2018, p. 02).

Professors Hunziker \& Krap (1942) defined tourism as "the totality of the relationship and phenomenon arising from the travel and stay of strangers, provided the stay does not imply the establishment of a permanent residence and is not connected with remunerated activity" (Raj, 2002, p. 69).

In 1991, the United Nations World Tourism Organisation declared that "Tourism comprises the activities of persons travelling to and staying in places outside of their usual environment for not more than one consecutive year for leisure, business or other purposes" (Camilleri, 2018, p. 02). 


\subsubsection{The tourism market}

The tourism market is defined by tourist demand and tourist supply.

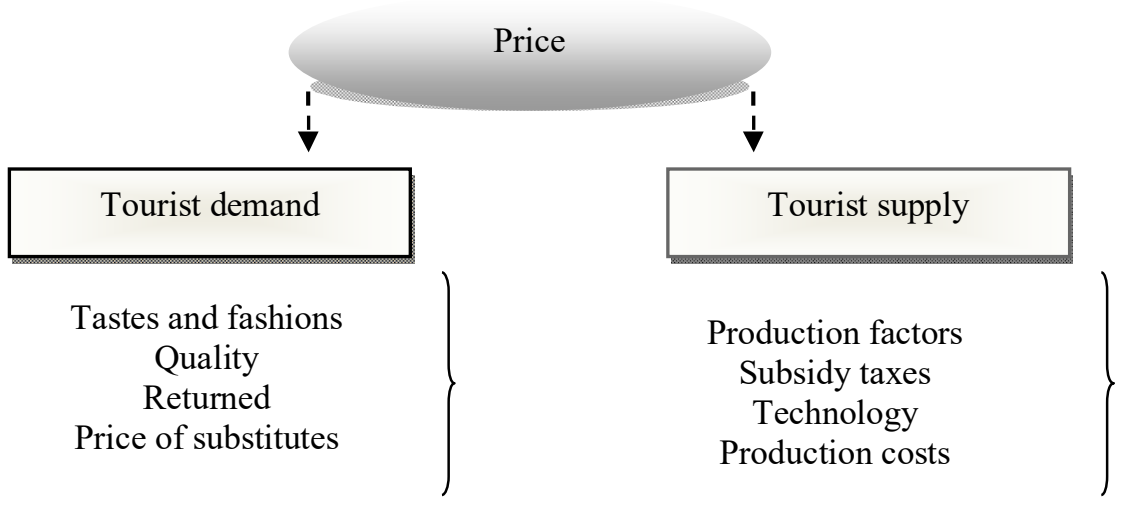

Figure 1. The tourism market Source: (Caccomo, 2007, p. 19)

\subsubsection{Tourist demand}

Tourism demand is defined based on total tourist spending on goods and services of domestic production.

In 1972, René Baretje introduced the function which links tourist demand to Xk factors like this:

$\mathrm{Y}=\mathrm{f}\left(\mathrm{X}_{1}, \mathrm{X}_{2}, \ldots, \mathrm{X}_{\mathrm{k}}\right) \quad$ with $\quad \mathrm{f}^{\prime}<0$

This translates to an increase in prices that will automatically cause a decrease in the quantities. This law applies to the tourist sector, so if the price of a stay increases, its demand falls and vice versa. 
Boumedyen Taibi \& The Impact of Tourism Industry on Economic Growth: the Khadidja Lamri

Case of Algeria (Cointegration \& Causal Analysis)

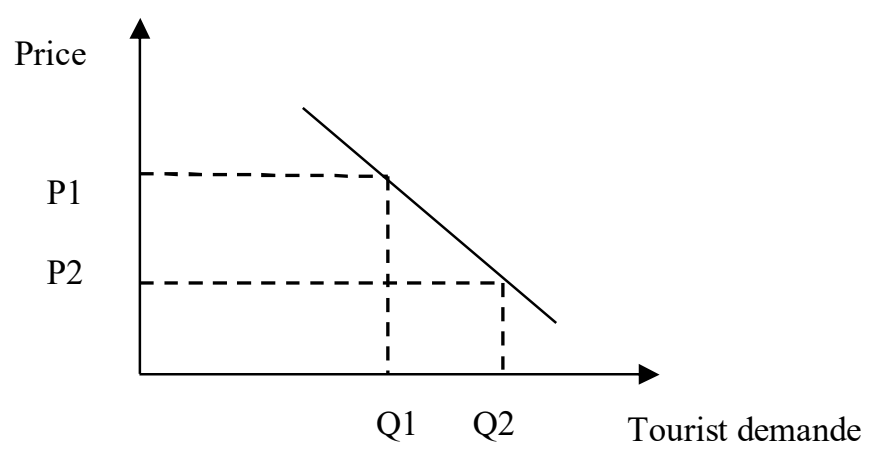

Figure 2. The tourist demand curve

\subsubsection{Tourist supply}

The tourist supply can be defined as the quantity of goods and services presented at a given price. Thus, the tourist offer is presented as a (basket) of goods and services offered to consumers to satisfy their needs. What is offered to consuming tourists is, in fact, a set of by-products (accommodation, transport, entertainment, and environment).

$\mathrm{Y}=\mathrm{f}\left(\mathrm{X}_{1}, \mathrm{X}_{2}, \ldots, \mathrm{X}_{\mathrm{k}}\right) \quad$ with $\quad \mathrm{f}^{\prime}>0$

This translates to An increase in prices will automatically cause an increase in the quantities.

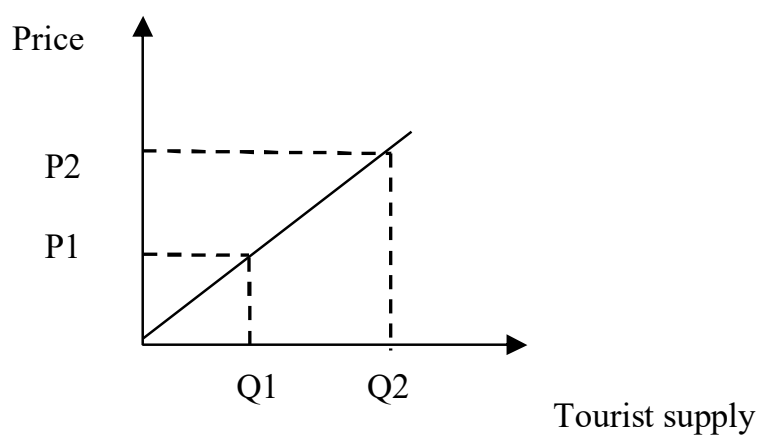

Figure 3. The tourist supply curve

The tourism product consists of a set of activities. It is a basket of several products and services of a different nature and composition with special characteristics. It is a composite product offering a set of material goods (hotel, craft products, etc.) and services of natural resources 
(landscape, beach, flora and fauna, etc.), socio-cultural resources (museums, etc.) and resources, technological (factory, nuclear power plants, etc.) and human relations, of the same importance.

\section{Methods}

The estimation of the empirical model took place in four stages:

- We will perform unit root tests on each model's variables to ensure the econometric approach follows.

- We will look for a cointegration relationship between the variables.

- Based on the cointegration relationship found, we will estimate a medium and long-term model.

In the end, we will evaluate the robustness of the model selected using the appropriate tests. As a final step, we will determine the trend of the relationship between economic growth and the tourism industry by the Granger causality test.

\subsection{ADF test}

Before the treatment of a time series, stochastic characteristics should be studied. If these characteristics - that is, its expectancy and variance- are modified over time, the time series is considered nonstationary. In the case of an invariant stochastic process, the time series is then stationary.

In a formalized way, the stochastic process yt is stationary if: (Bourbonnais, 2015, pp. 239-240)

- $\mathrm{E}\left(\mathrm{y}_{\mathrm{t}}\right)=\mathrm{E}\left(\mathrm{y}_{\mathrm{t}+\mathrm{m}}\right)=\mu \quad \forall \mathrm{t}$ and $\forall \mathrm{m}$, the average is constant and independent of time.

- $\operatorname{Var}\left(\mathrm{y}_{\mathrm{t}}\right)<\infty \forall \mathrm{t}$, the variance is finite and independent of time.

- $\operatorname{cov}\left(\mathrm{y}_{\mathrm{t}}, \mathrm{y}_{\mathrm{t}+\mathrm{k}}\right)=\mathrm{E}\left[\left(\mathrm{y}_{\mathrm{t}}-\mu\right)\left(\mathrm{y}_{\mathrm{t}+\mathrm{k}}-\mu\right)\right]=\gamma_{\mathrm{k}}$, the covariance is independent of time.

It appears from these properties that a white noise process $\varepsilon t$ in which the $\varepsilon t$ are independent and of the same law $N(0, \sigma 2 \varepsilon)$ is stationary.

A time series is, therefore, stationary if it is the realization of a stationary process. This implies that the series have neither trend nor seasonality and, more generally, no factor changing over time (Bourbonnais, 2015, p. 240)

The stationarity test used is that of Augmented Dickey-Fuller (ADF, 1981). This test exists in three different versions:

The first model without constant or deterministic trend is presented as follows:

$$
\Delta Y_{\mathrm{t}}=\alpha Y_{\mathrm{t}-1}-\sum_{j=2}^{p} \phi_{\mathrm{j}} \Delta Y_{\mathrm{t}-\mathrm{j}+1}+\varepsilon_{\mathrm{t}}
$$


The second model with constant and without deterministic trend:

$$
\Delta Y_{\mathrm{t}}=\alpha Y_{\mathrm{t}-1}-\sum_{j=2}^{p} \phi_{\mathrm{j}} \Delta Y_{\mathrm{t}-\mathrm{j}+1}+c+\varepsilon_{\mathrm{t}}
$$

The third model with the constant and deterministic trend:

$$
\Delta Y_{\mathrm{t}}=\alpha Y_{\mathrm{t}-1}-\sum_{j=2}^{p} \phi_{\mathrm{j}} \Delta Y_{\mathrm{t}-\mathrm{j}+1}+c+\beta t+\varepsilon_{\mathrm{t}}
$$

Where $\Delta \mathrm{Y}$ " $\mathrm{t}$ " is the change between periods $\mathrm{t}$ and $\mathrm{t}+1$, the null hypothesis $\mathrm{H} 0$ of non-stationarity is evaluated by testing the hypothesis $\varphi=1$, which means there is a unit root.

\subsection{Johansen's cointegration test (1988)}

The study of cointegration makes it possible to test the existence of a stable long-term relationship between two non-stationary variables, including delay variables and exogenous variables. There are several tests of cointegration, the most general being Johansen's. Whatever the test is chosen, it has significance only on non-stationary long series. Therefore, the cointegration analysis makes it possible to identify the true relationship between two variables by looking for the existence of a cointegrating vector and eliminating its effect if necessary.

Two series, $\mathrm{x}$ and $\mathrm{y}$, are cointegrated if the following two conditions are satisfied: they are assigned a stochastic trend of the same order of integration, and a linear combination of these series allows them to reduce to a series of the order of integration inferior (Dupont, 2009).

To determine the number of cointegration relationships, Johansen (1988) proposes two tests based on the eigenvalue of a matrix derived from a two-step calculation:

Calculation of two residues $u_{t}$ and $v_{t}$ by making two regressions:

The first :

$$
\begin{aligned}
& \Delta Y_{\mathrm{t}}=\widehat{A_{0}}+\widehat{A_{1}} \Delta Y_{\mathrm{t}-1}+\widehat{A_{2}} \Delta Y_{\mathrm{t}-2}+\cdots+\widehat{A_{\mathrm{p}}} \Delta Y_{\mathrm{t}-\mathrm{p}}+u_{\mathrm{t}} \\
& \text { The second: }
\end{aligned}
$$

$$
\Delta \mathrm{Y}_{\mathrm{t}-1}=\widehat{\mathrm{A}_{0}^{\prime}}+\widehat{\mathrm{A}_{1}^{\prime}} \Delta \mathrm{Y}_{\mathrm{t}-1}+{\widehat{\mathrm{A}_{2}}}^{\prime} \Delta \mathrm{Y}_{\mathrm{t}-2}+\cdots+\widehat{\mathrm{A}}_{\mathrm{p}}^{\prime} \Delta \mathrm{Y}_{\mathrm{t}-\mathrm{p}}+v_{\mathrm{t}}
$$

$$
\text { With: } Y_{\mathrm{t}}=\begin{gathered}
y_{1, \mathrm{t}} \\
y_{2, \mathrm{t}} \\
\ldots: \\
y_{\mathrm{k}, \mathrm{t}}
\end{gathered}
$$


$u_{t}$ and $v_{t}$ are the matrices of the residuals of dimension $(\mathrm{k}, \mathrm{n})$, with $\mathrm{k}$ number of variables, n: number of observations.

$$
\begin{aligned}
& \widehat{\sum_{u u}}=\left(\frac{1}{n}\right) \sum_{i=1}^{n} u_{\mathrm{t}} u_{\mathrm{t}}{ }^{\prime} \\
& \widehat{\sum_{v v}}=\left(\frac{1}{n}\right) \sum_{i=1}^{n} v_{\mathrm{t}} v_{\mathrm{t}}{ }^{\prime} \\
& \sum_{u v}=\left(\frac{1}{n}\right) \sum_{i=1}^{n} u_{\mathrm{t}} v_{\mathrm{t}}{ }^{\prime} \\
& \sum_{v u}=\left(\frac{1}{n}\right) \sum_{i=1}^{n} v_{\mathrm{t}} u_{\mathrm{t}}{ }^{\prime}
\end{aligned}
$$

Extracting the $\mathrm{k}$ eigenvalues of the matrix $\mathrm{M}$ of dimension $\mathrm{k}$ : $\mathrm{k}$ in the following manner:

$$
M=\widehat{\sum_{v v}^{-1}} \cdot \widehat{\sum_{v i}} \cdot \widehat{\sum_{u i}^{-1}} \cdot \widehat{\sum_{u v}}
$$

The number of cointegration relationships is tested by the (Trace) (Likelihood ratio) statistic provided by Johansen, written:

$$
\lambda_{\text {trace }}=-n \sum_{i=r+1}^{k} \ln \left(1-\lambda_{\mathrm{i}}\right)
$$

With $\mathrm{n}$ : number of observations, $\lambda_{\mathrm{i}}$ eigenvalue of the matrix $\mathrm{M}, \mathrm{k}$ : number of variables, $r$ : rank of the matrix. This statistic follows a probability distribution similar to $\mathrm{x}^{2}$ tabulated using simulation by Johansen and Juselius (1990). The trace test works by excluding alternative hypotheses:

The rank of the matrix $\mathrm{r}=0$, ie $\mathrm{H}_{0}: \mathrm{r}=0$ against $\mathrm{H}_{1}: \mathrm{r}>0$, if $\mathrm{H}_{0}$ is refused we proceed to the next test $(\lambda$ trace $>$ the critical value read in the table), in the opposite case, the procedure is stopped and the rank of the matrix is $r=0$.

After having rejected different hypotheses $\mathrm{H}_{0}$ at the end of the procedure, we test $\mathrm{H}_{0}: \mathrm{r}=\mathrm{k}-1$ against $\mathrm{H}_{1}: \mathrm{r}=\mathrm{k}$. If we refuse $\mathrm{H}_{0}$, then the rank of the matrix is $r=k$, and there is no cointegration relation because the variables are all I (0).

The statistic of the maximum eigenvalue gives the second test proposed by Johansen:

$$
\lambda_{\max }=-n \log \left(1-\lambda_{\mathrm{r}+1}\right)
$$


Boumedyen Taibi \& The Impact of Tourism Industry on Economic Growth: the

Khadidja Lamri

Case of Algeria (Cointegration \& Causal Analysis)

The test is carried out sequentially by excluding alternative hypotheses, like the trace test. In case of divergence of the two tests: trace and maximum eigenvalue, the test of the trace with the highest power is preferred.

\subsection{Estimation of a vector error correction model (VECM)}

This type of econometric specification is known as the partial adjustment or error correction mechanism. Hendry popularized the latter type of specification under the general theme of error correction models (ECM) Davidson, Hendry, Srba \& Yeo (1978) (Maurel, 1989, p. 105). The approach of this model allows us to determine both short-term and longterm properties at the same time.

\subsection{Model validation}

To test the normality of the residuals, we use the J-B test from JARQUE and BERA. This test follows a distribution of "Chi-square" with two degrees of freedom. It is frequently used to determine whether the residuals of a linear regression follow a normal distribution.

The test of J-B formulates the null hypothesis of the normal distribution of the residues, and this hypothesis is accepted if the statistic J$\mathrm{B}$ is lower than the critical value of 5.99. This normality of the residuals is also accepted when the critical probability is superior to the $5 \%$ threshold (Mignon \& Lardic, 2002, p. 275).

The Jarque-Bera statistic is written (Damodar Gurrati, 2004, p. 149):

$$
J B=\frac{n-k}{6}\left[s^{2}+\frac{(K-3)^{2}}{4}\right]
$$

With:

$\mathrm{n}$ : Number of observations

$\mathrm{k}$ : Number of explanatory variables if the data come from the residues of linear regression. Otherwise, $\mathrm{k}=0$.

$\mathrm{s}$ : Coefficient of asymmetry of the test sample.

$\mathrm{K}$ : Kurtosis of the tested sample.

$\mathrm{s}$ and $\mathrm{K}$ are defined by:

$$
\begin{gathered}
S=\frac{\widehat{\mu}_{3}}{\widehat{\sigma}_{3}}=\frac{\frac{1}{n} \sum_{i=1}^{n}\left(x_{\mathrm{i}}-\bar{x}\right)^{3}}{\left(\frac{1}{n} \sum_{i=1}^{n}\left(x_{\mathrm{i}}-\bar{x}\right)^{2}\right)^{\frac{3}{2}}} \\
K=\frac{\widehat{\mu}_{4}}{\widehat{\sigma}_{4}}=\frac{\frac{1}{n} \sum_{i=1}^{n}\left(x_{\mathrm{i}}-\bar{x}\right)^{4}}{\left(\frac{1}{n} \sum_{i=1}^{n}\left(x_{\mathrm{i}}-\bar{x}\right)^{2}\right)^{2}}
\end{gathered}
$$


With:

$\hat{\mu}_{3}, \hat{\mu}_{4}$ the estimators of the third and fourth moments, $\bar{x}:$ is the mean of the sample and $\hat{\sigma}^{2}$ is the variance of the sample.

\subsection{Granger causality}

Causality, defined by Granger (1969) and Sims (1972), is inferred when lagged values of a variable, say $\mathrm{x}_{\mathrm{t}}$, have explanatory power in a regression of a variable $y_{t}$ on lagged values of $y_{t}$ and $x_{t}$. The VAR can be used to test the hypothesis. Tests of the restrictions can be based on simple F tests in the single equations of the VAR model. That the unrestricted equations have identical regressors means that these tests can be based on the results of simple Ordinary Least Squares (OLS) estimates. The notion can be extended in equations to ascertain if a given variable is weakly exogenous to the system. If lagged values of a variable $\mathrm{x}_{\mathrm{t}}$ have no explanatory power for any of the variables in a system, then we would view $\mathrm{x}$ as weakly exogenous to the system. Once again, this specification can be tested with a likelihood ratio test, as described below. The restriction will be to put (holes) in one or more matrices or with a form of $F$ test constructed by stacking the equations (Greene, 2002, p. 592).

\section{Results and discussion}

Globally, tourism has become widely recognized by governments, many international business houses and financing agencies as an effective way to raise the level of development of a country's economy; to the extent that emerging economies like India are beginning to think that they are an alternative source of economic growth, therefore, in this section, we will study the impact of the tourism sector on economic growth in Algeria for the period 1990-2018 and analyze the results.

\subsection{Presentation of model variables}

\subsubsection{Presentation of the model}

In this study, we used the following reduced equation:

$$
\mathrm{GDP}_{\mathrm{t}}=\beta_{0}+\beta_{1} \mathrm{NBT}_{\mathrm{t}}+\beta_{2} \quad \mathrm{REER}_{\mathrm{t}}+\varepsilon_{\mathrm{it}}
$$

With:

GDP: Gross domestic product.

$\beta_{0}$ : Constant.

NBT: Number of tourists.

REER: Real effective exchange rate. 


\section{$\varepsilon_{\text {it: }}:$ Error term.}

The empirical model of equation 8 can be expressed in logarithmic form as follows:

$$
\operatorname{Ln} \mathrm{GDP}_{\mathrm{t}}=\beta_{0}+\beta_{1} \operatorname{lnNBT}_{\mathrm{t}}+\beta_{2} \quad \operatorname{lnREER}_{\mathrm{t}}+\varepsilon_{\mathrm{it}}
$$

The logarithmic form was used to linearize and homogenize the data.

\subsubsection{Data sources and variables}

The variables of this study are:

- Gross domestic product (GDP), the number of tourists (NBT), real effective exchange rate (REER)

- Annual data from 1995 to 2018 were obtained from the World Bank Development.

\subsection{Empirical results}

In this section, we will present our empirical results.

\subsubsection{Graphical presentation of variables}

Before any time series analysis, it is essential to study the graph representing its evolution carefully because it provides a priori with a global idea of the nature and the characteristics of the processes generating this series, namely the seasonality trend etc.

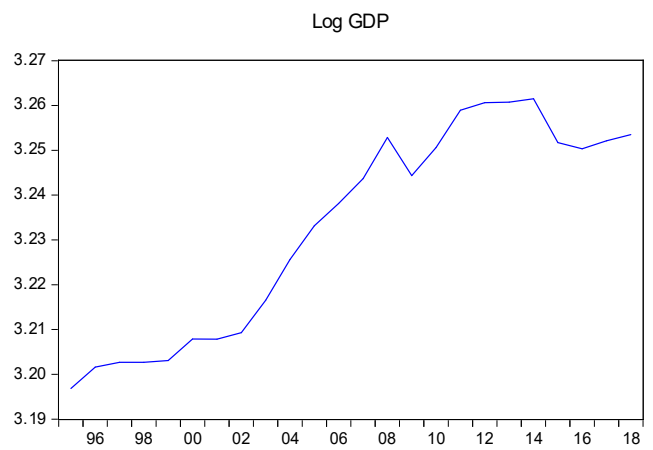

Figure 4. Gross domestic product Source: Results obtained from Eviews9

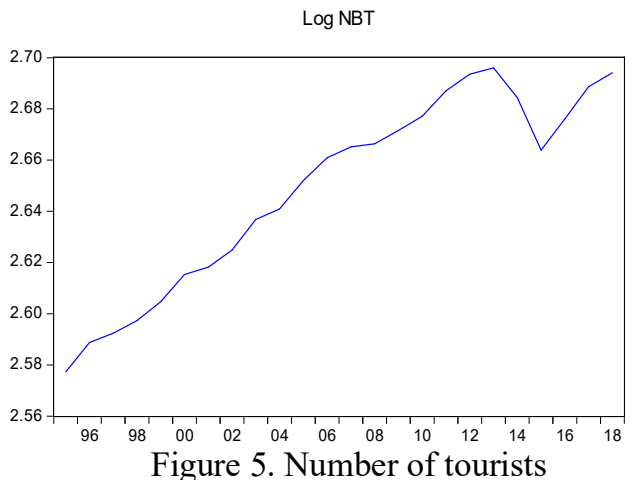

Source: Results obtained from Eviews 9 


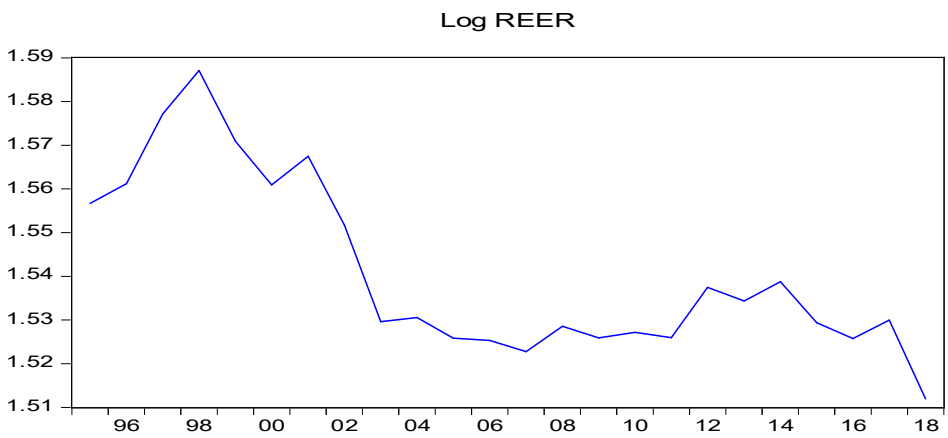

Figure 6. Real effective exchange rate

Source: Results obtained from Eviews 9

The graphical representation of our raw series shows that there is a trend. So probably, this series is not stationary. For confirmation, we will apply the stationarity test.

\subsubsection{ADF test}

The ADF test on our series is presented in the following table. We took the model with Intercept:

Table 1. ADF test with Intercept on the GDP, NBT, REER series

\begin{tabular}{lcccc}
\hline Variable & t-Statistic & Critical values & Probability & Order \\
\hline GDP & -3.889942 & -3.004861 & 0.0077 & $\mathrm{I}(1)$ \\
NBT & -3.384542 & -3.004861 & 0.0229 & $\mathrm{I}(1)$ \\
REER & -3.918533 & -3.004861 & 0.0072 & $\mathrm{I}(1)$ \\
\hline
\end{tabular}

Source: Prepared by the researchers, based on outputs of Eviews 9 .

The result confirms that the series is not stationary in level and are all integrated into order 1 . They are, therefore, stationary in the first difference.

\subsubsection{Cointegration test - Johansen (1988)}

The trace value gives the test relating to the number of cointegration relations. We apply the test of Johansen (1988) to determine the number of cointegration vectors. The cointegration test is presented in the following table. 
Boumedyen Taibi \& The Impact of Tourism Industry on Economic Growth: the

Khadidja Lamri

Case of Algeria (Cointegration \& Causal Analysis)

Table 2. Trace test

\begin{tabular}{ccccc}
\hline $\begin{array}{c}\text { Hypothesized } \\
\text { No.of CE }(\mathrm{s})\end{array}$ & Eigenvalue & Trace statistic & $\begin{array}{c}\text { Critical value } \\
0.05\end{array}$ & Probability \\
\hline None & 0.687756 & 37.42953 & 29.79707 & 0.0055 \\
At most 01 & 0.383108 & 11.82219 & 15.49471 & 0.1657 \\
At most 02 & 0.052863 & 1.194846 & 3.841466 & 0.2744 \\
\hline
\end{tabular}

Source: Prepared by the researchers, based on outputs of Eviews 9.

According to Table 2 and based on Johansen statistics, we reject, at the $5 \%$ threshold $(37.42953>29.79707$ for the trace), the null hypothesis $\mathrm{H} 0$, the absence of cointegration relation against the alternative hypothesis. (There is at least one cointegration relationship between the variables). So we accept the null hypothesis H0: at most one cointegration relation, against H1: there are at least two cointegration relations at the 5\% threshold $(11.82219<15.49471$ for the trace). We accept H0: the presence of a single cointegration relationship at the $5 \%$ threshold.

\subsubsection{Identification of the cointegration relationship}

$$
\begin{gathered}
\mathrm{GDP}=-0.977246 \mathrm{NBT}+0.906738 \mathrm{REER}-15.76355 \\
{[20.0121]}
\end{gathered}
$$

The estimation of the long-term relationship between the number of tourists confirmed that the NBT has a significant negative effect on the GDP (t-student > 1.96). On the other hand, the REER has a significant positive effect on NBT ( $\mathrm{t}$-student $>1.96)$.

\subsubsection{Estimation of a vector error correction model (VECM)}

After the estimation of a VECM model, we obtained the following dynamic equation:

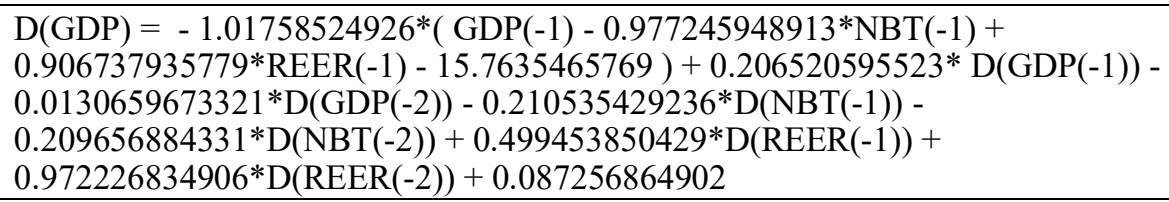

The adjustment coefficient or the recall force is negative -1.01 and more significant (t-student $>1.96$ ), so we conclude that the unit has a shortterm, long-term adjustment of $100 \%$.

\subsubsection{Model validation (J-B test)}

To test the normality of the residues, the J-B test was used. 


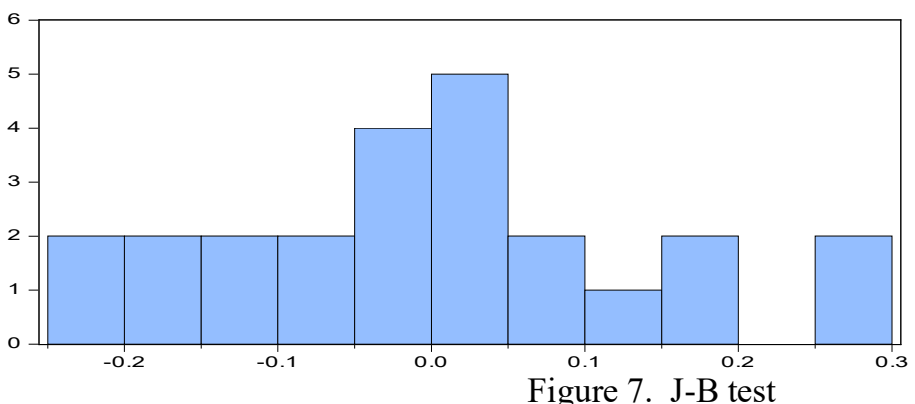

\begin{tabular}{|lr|}
\hline \multicolumn{2}{|l|}{ Series: Residuals } \\
Sample 1995 2018 \\
Observations 24 \\
Mean & $-1.48 e-16$ \\
Median & -0.004589 \\
Maximum & 0.259722 \\
Minimum & -0.220274 \\
Std. Dev. & 0.135243 \\
Skewness & 0.249474 \\
Kurtosis & 2.362844 \\
Jarque-Bera & 0.654916 \\
Probability & 0.720754 \\
\hline
\end{tabular}

Source: Results obtained from Eviews 9.

According to figure 7 , the J-B statistic is 0.65 with a probability of $72 \%$. We conclude that the residuals are normally distributed (the null hypothesis of normality is accepted).

\subsubsection{Granger causality test}

After confirming a long-term relationship, we are going through another step to determine the relationship trend between economic growth and the tourism industry. The Granger causality test illustrates this.

Table 3. Granger causality test

\begin{tabular}{lccc}
\hline \multicolumn{1}{c}{ Null hypothesis } & Observation & F- statistic & probability \\
\hline $\begin{array}{l}\text { NBT does not Granger } \\
\text { cause GDP }\end{array}$ & 22 & 5.44396 & 0.0149 \\
$\begin{array}{l}\text { GDP does not Granger } \\
\text { cause NBT }\end{array}$ & 22 & 0.27256 & 0.7647 \\
$\begin{array}{l}\text { REER does not Granger } \\
\text { cause GDP }\end{array}$ & 22 & 6.57027 & 0.0077 \\
$\begin{array}{l}\text { GDP does not Granger } \\
\text { cause REER }\end{array}$ & 22 & 0.43367 & 0.6551 \\
\hline
\end{tabular}

Source: Prepared by the researchers, based on outputs of Eviews 9

According to this table, six hypotheses were tested simultaneously: the causality between the two variables taken two by two at the 5\% threshold. It is clear from the table results that the causal relationship is in the same trend, meaning that the NBT causes economic growth (GDP). Furthermore, still at the 5\% threshold, the REER influences the GDP and not vice versa.

\section{Conclusion}

This article has attempted to analyze the relationship between tourism and economic growth in Algeria from 1995-2018. To achieve this 
goal, four tests were used: the stationarity test, the Johansen cointegration test, the correction error test and the Granger causality test. The results showed that:

- The series of variables, GDP, NBT, and REER, are stationary in the first difference

- The three variables are cointegrated. They evolve together and consequently display a long-term relationship, at least in one trend

- The estimation of a VECM model shows that there is a short-term and long-term adjustment of $100 \%$

- In Granger's sense, NBT causes GDP and not the reverse, and the REER has an influence on the GDP and not vice versa

On the economic plan:

To examine our four hypotheses posed previously:

- The tourism sector has a positive impact on economic growth in Algeria The tourism sector has a negative impact on economic growth in Algeria

- The NBT and REER caused the GDP

- The NBT and REER do not cause the GDP

- The effect of NBT on GDP is negative, so we accept H2.

- The results showed that the NBT and REER cause GDP, so we accept H3.

Algeria adopted new policies to revive the Algerian economy represented in the development of the tourism sector, in which this policy achieved a positive result. However, Algeria did not maintain this policy.

It can be said that tourism development in Algeria has become imperative, despite what Algeria possesses of oil wealth, which must be used to strengthen the infrastructure for the development of non-oil economic sectors to achieve the principle of sustainable development and avoid financial crises resulting from fluctuations in the oil market.

In the context of economic diversification, Algeria should promote Halal tourism, which aims to provide travel services following Islamic principles.

\section{References}

Arslanturk, Y., Balcilar, M., \& Ozdemir, Z. A. (2011). Time-varying linkages between tourism receipts and economic growth in a small open economy. Economic Modelling, 28(1), 664-671. https://doi.org/https://doi.org/10.1016/j.econmod.2010.06.003

Ben Zaarour, C., \& Satour, R. (2017). Tourism and economic growth in Algeria: Evidence of Cointegration and causal analysis. MPRA Paper No 78731. Retrieved from https://mpra.ub.unimuenchen.de/78731/1/MPRA_paper_78731.pdf. 
Bourbonnais, R. (2015). Econométrie : cours et exercice corrigés [Econometrics: corrected course and exercise]. Paris: édition Dunod. Caccomo, J. L. (2007). Fondements d'économie du tourisme [Foundations of tourism economics]. Belgique: édition de Boeck.

Camilleri, M. A. (2018). The Tourism Industry: An Overview. In Travel Marketing, Tourism Economics and the Airline Product: An Introduction to Theory and Practice (pp. 3-27). https://doi.org/10.1007/978-3-319-49849-2_1

Cazes, G. (1989). Le Tourisme international: Mirāge ou stratégie d'avenir? [International Tourism: Mirage or strategy for the future?]. Paris: Hatier.

Damodar, N. G. (2004). Econométrie [Econometrics]. Paris: édition de Boeck .

Dupont, L. (2009). Cointégration et causalité entre développement touristique, croissance économique et réduction de la pauvreté : cas de Haïti [Cointegration and causality between tourism development, economic growth and poverty reduction: the case of Haiti]. Etudes caribéennes, 13-14.

Ekanayake, E., \& Aubrey, E, L. (2012). Tourism development and economic growth in developing countries. The International Journal of Business and Finance Research, 6 (1), 51-63.

Greene, W. H. (2002). Econometric Analysis. $5^{\text {th }}$ Edition, Prentice-Hall, Upper Saddle River.

Harrats, H., \& Ramdani, M. (2018). Drash al'elaqh alsbbyh byn alastthmar alsyahy walnmw alsyahy fy aljza'er balast'emal mnjyb Toda And Yamamoto [Studying the causal relationship between tourism investment and tourism growth in Algeria using Toda and Yamamoto methodology]. Al Bashaer Economic Journal, 4 (2), 134-164.

Maurel, F. (1989). Modèles à correction d'erreur : l'apport de la théorie de cointégration [Error correction models: the contribution of cointegration theory]. Economie et Prévision , 88(2), 105-125.

Mignon V., \& Lardic S. (2002). Econométrie des séries temporelles macroéconomiques et financières [Econometrics of macroeconomic and financial time series]. Paris: Economica.

Raj, K. (2002). Modern Dictionary of Tourism. New Delhi: Sarup \& Sons.

(C) 2020 the Author(s). This is an open access article distributed under the terms of Creative Commons Attribution-Non Commercial License (CC BY-NC 4.0) which permits use, distribution and reproduction in any medium, provided the original work is properly cited and is not used for commercial purposes.

Recommended citation :

Taibi, B., \& Lamri, K. (2020). The Impact of Tourism Industry on Economic Growth: The Case of Algeria (Cointegration \& Causal Analysis). Management \& Economics Research Journal, 2(4), 1026. https://mer-j.com/merj/index.php/merj/article/view/122 